\title{
ANALISIS YURIDIS PENERAPAN SANKSI PIDANA TERHADAP PELAKU TINDAK PIDANA PERUSAKAN HUTAN LINDUNG MENURUT UNDANG- UNDANG NOMOR 32 TAHUN 2009 TENTANG PERLINDUNGAN DAN PENGELOLAAN LINGKUNGAN HIDUP
}

\author{
oleh \\ Arif Rusmana \\ Hana Krisnamurti
}

\begin{abstract}
ABSTRAK
Perusakan hutan secara umum dapat diartikan sebagai kegiatan yang berupa menduduki atau menggunakan kawasan hutan secara tidak sah, merambah kawasan hutan (melakukan perencekan), penebangan, pengangkutan, dan penjualan kayu yang tidak sah atau tidak memiliki izin dari otoritas setempat, melakukan eksplorasi atau eksploitasi bahan tambang didalam dikawasan hutan tanpa izin yang sah dan mengeluarkan, membawa dan mengangkat tumbuh-tumbuhan dan satwa liar yang tidak dilindungi Undang-Undang berasal dari kawasan hutan tanpa izin dari pejabat yang berwenang. Penelitian ini dilakukan untuk mengnalisis penerapan Sanksi Pidana terhadap pelaku tindak pidana perusakan hutan lindung menurut Undang-Undang Nomor 32 Tahun 2009 Tentang Perlindungan dan Pengelolaan Lingkungan Hidup dihubungkan dengan Undang-Undang Nomor 18 tahun 2013 tentang pemberantasan dan pencegahan perusakan hutan dan Menganalisis upaya pencegahan terhadap tindak pidana perusakan hutan lindung. Hasil penelitian memperoleh kesimpulan bahwaUndang-undang yang diterapkan terhadap perusahaan-perusahaan yang telah melanggar perizinan dalam kasus perusakan hutan lindung di Kabupaten Garut adalah Pasal 98 ayat (1) dan Pasal 109 UUPPLH karena para pelaku telah memenuhi unsur-unsur yang terdapat didalam pasal tersebut, dan dalam hal ini pihak kepolisian masih dalam tahap penyidikan. Untuk kasus yang terjadi dikabupaten Bandung para pelaku hanya mendapat teguran serta peringatan dari pihak terkait untuk tidak menggunakan areal hutan dengan tidak bijaksana, hal itu dilakukan mengingat semua pelaku adalah warga setempat yang bersinggungan langsung dengan kawasan terebut.Tetapi meski demikian seharusnya hal tersebut tidak menghilangkan tindak pidana yang telah diperbuat dan seharusnya pelaku tetap diterapkan pasal mengenai tindak pidana yang terdapat dalam UPPLH ataupun UUP3H.Adapun upaya pencegahan terhadap tindak pidana perusakan hutan dapat dilakukan dengan tiga upaya yaitu, Upaya preventif dengan cara mengadakan sosialisasi pentingnya hutan lindung dan juga ikut mengawasi kegiatan yang dilakukan diareal hutan, upaya represif dengan cara menerapkan sanksi pidana ataupun administrasi terhadap pelanggar dan upaya kuratif dengan cara penanaman hutan kembali terhadap hutan-hutan yang terlanjur gundul.
\end{abstract}

\section{PENDAHULUAN}

\section{Latar Belakang}

Hutan adalah suatu wilayah yang memiliki banyak tumbuh-tumbuhan lebat yang berisi antara pohon, semak, paku-pakuan, jamur dan lain sebagainya serta menempati daerah yang cukup luas. Hutan adalah suatu areal yang luas dikuasai oleh pohon tetapi hutan bukan hanya sekedar pohon, termasuk didalamnya tumbuhan kecil seperti lumut, semak belukar, dan bunga-bunga hutan. Didalam hutan juga terdapat beraneka ragam burung, serangga, dan berbagai jenis binatang yang menjadikan hutan sebagai habitatnya. ${ }^{1}$

Hutan di Indonesia memiliki peran yang sangat penting baik ditinjau dari aspek ekonomi, sosial, budaya maupun ekologi. Namun meski demikian seiring dengan

\footnotetext{
${ }^{1}$ Supardi, Hukum Kehutanan Dan Perkebunan Di Indonesia, Sinar Grafika, jakarta, 2011, hlm.1
} 
pertambahan penduduk dan pertumbuhan nasioanal, tekanan terhadap sumber daya hutanpun semakin meningkat. Sumber daya hutan memiliki fungsi yang sangat penting sebagai sistem penyangga kehidupan manusia, untuk mendukung fungsi tersebut pemerintah telah menata kawasan hutan dengan fungsi utamanya masing-masing yang dituangkan dalam UndangUndang Nomor 4 Tahun 1999 Tentang Kehutanan (selanjutnya disebut UUK) yaitu :

a) Hutan produksi, kawasan hutan yang mempunyai fungsi pokok untuk memproduksi hasil hutan.

b) Hutan lindung, kawasan hutan yang mempunyai fungsi pokok sebagai perlindungan sistem penyangga kehidupan untuk mengatur tata air, mencegah banjir, mengendalikan erosi, mencegah institusi air laut dan memelihara kesuburan tanah.

c) Hutan konservasi, untuk tujuan pengawetan keanekaragaman tumbuhan dan satwa serta ekosistemnya yang juga berfungsi sebagai wilayah sistem penyangga kehidupan.

Pemanfaatan hutan merupakan kegiatan untuk memanfaatkan kawasan hutan, memanfaatkan jasa lingkungan, memanfaatkan hasil hutan kayu dan hasil hutan non kayu serta memungut hasil hutan kayu dan bukan kayu secara optimal dan adil untuk kesejahteraan masyarakat dengan tetap menjaga kelestarianya. Pada pasal 19 ayat UUK menyatakan, "perubahan peruntukan dan fungsi kawasan hutan ditetapkan oleh pemerintah dengan didasarkan pada hasil penelitian terpadu". Tentu alih fungsi hutan tidak boleh dilakukan sembarangan agar tidak menimbulkan dampak yang negatif.

Adanya kerusakan hutan yang terjadi dibeberapa daerah yang telah terjadi di Indonesia adalah karena kesengajaan yang dilakukan manusia. Masyarakat sengaja merusak dan membakar hutan yang bertujuan untuk memperluas lahan garapanya dan selain itu membakar lahan juga dianggap dapat meningkatkan kesuburan tanah, walaupun sifatnya hanya sementara saja dan malah merusak tanah itu sendiri. ${ }^{2}$

Kerusakan hutan yang terjadi dikawasan Darajat, kecamatan Pasirwangi, kabupaten Garut diakibatkan karena banyaknya penyalahgunaan alih fungsi hutan lindung, mulai dari pembuatan wana wisata seperti wisata alam, pemandian air panas, kolam renang, restoran serta penginapan. Yang lebih berdampak besar ketika banyaknya pembukaan lahan hutan secara ilegal oleh masyarakat setempat untuk dijadikan lahan pertanian, sedangkan hutan tersebut peruntukanya bukan untuk pertanian, tetapi karena banyaknya masyarakat yang melakukan pembukaan lahan secara ilegal maka dampak terhadap lingkunganpun semakin besar diantaranya banjir, longsor, rusaknya ekosistem yang ada dihutan, serta kelestarian fungsi hutan yang terganggu. Sampai saat ini sudah ada tujuh orang yang ditetapkan tersangka oleh Dit Reskrimsus Polda Jawa Barat terhadap pelaku penyalah gunaan pengelolaan dan pemanfaatan hutan lindung di kabupaten Garut.

Selain dikabupaten Garut tindak pidanaPerusakan hutan lindung juga terjadi di kabupaten Bandung, lahan hutan yang semula merupakan hutan lindung sekarang beralih fungsi menjadi lahan pertanian. Lahan milik perhutani Di Blok Waas Dewata, Pasirjambu, Kabupaten Bandung tersebut lebih dari setengah kawasan hutan lindung dimanfaatkan sebagai lahan pertanian oleh warga setempat.

\section{Identifikasi Masalah}

1. Bagaimanakah penerapan Sanksi Pidana terhadap pelaku tindak pidana perusakan hutan lindung menurut Undang-Undang Nomor 32 Tahun 2009 Tentang Perlindungan dan Pengelolaan Lingkungan Hidupdihubungkan dengan Undang-Undang Nomor 18 tahun 2013 tentang pemberantasan dan pencegahan perusakan hutan?

2. Bagaimanakah upaya pencegahan terhadap tindak pidana perusakan hutan lindung?

\footnotetext{
${ }^{2}$ Gatot Suparmono, Penyelesaian Sengketa Lingkungan Hidup Di Indonesia, Rineka Cipta, Jakarta 2013,
} 


\section{TINJAUAN PUSTAKA}

\section{Tindak Pidana Perusakan Hutan Lindung}

Kerusakan hutan, terutama berupa pembalakan liar, penambangan tanpa izin, dan perkebunan tanpa izin telah banyak menimbulkan kerugian untuk masyarakat sekitar wilayah hutan tersebut dalam hal lingkungan hidup, serta meningkatnya pemanasan global yang telah menjadi isu regional, nasional dan internasional. Kerusakan hutan sudah menjadi kejahatan yang berdampak luar biasa yang mengancam kelangsungan kehidupan bermasyarakat, dalam rangka pemberantasan serta pencegahan diperlukan langkah yang efektif dan pemberian efek jera maka diperlukan landasan hukum yang kuat dan yang mampu menjamin efektifitas penegkan hukum.

Pencegahan perusakan hutan merupakan segala upaya yang dilakukan untuk menghilangkan kesempatan terjadinya perusakan hutan, sedangkan pemberantasan perusakan hutan adalah segala upaya yang dilakukan untuk menindak secara hukum terhadap pelaku perusakan hutan baik langsung, tidak langsung, maupun yang terkait lainya. Menurut pasal 1 angka 3 UUP3H menyatakan:

"Perusakan huta adalah proses, cara, atau perbuatan merusak hutan melalui kegiatan pembalakan liar, penggunaan kawasan hutan tanpa izin atau penggunaan izin yang bertentangan dengan maksud dan tujuan pemberian izin dikawasan hutan yang telah ditetapkan, yang telah ditunjuk, ataupun yang sedang di proses penetapanya oleh pemerintah"

Perbuatan yang dilarang yang dikategorikan sebagai perbuatan-perbuatan perusakan hutan salah satunya terdapat dalm rumusan pasal 12, 14, 15, 17, 19-28 UUP3H tahun 2013

Pasal 12 UUP3H No 18 tahun 2013 Setiap orang dilarang:

a. melakukan penebangan pohon dalam kawasan hutan yang tidak sesuai dengan izin pemanfaatan hutan";

b. melakukan penebangan pohon dalam kawasan hutan tanpa memiliki izin yang dikeluarkan oleh pejabat yang berwenang;

c. melakukan penebangan pohon dalam kawasan hutan secara tidak sah;

d. memuat, membongkar, mengeluarkan, mengangkut, menguasai, dan/atau memiliki hasil penebangan di kawasan hutan tanpa izin;

e. mengangkut, menguasai, atau memiliki hasil hutan kayu yang tidak dilengkapi secara bersama surat keterangan sahnya hasil hutan;

f. membawa alat-alat yang lazim digunakan untuk menebang, memotong, atau membelah pohon di dalam kawasan hutan tanpa izin pejabat yang berwenang;

g. membawa alat-alat berat dan/atau alat-alat lainnya yang lazim atau patut diduga akan digunakan untuk mengangkut hasil hutan di dalam kawasan hutan tanpa izin pejabat yang berwenang;

h. memanfaatkan hasil hutan kayu yang diduga berasal dari hasil pembalakan liar;

i. mengedarkan kayu hasil pembalakan liar melalui darat, perairan, atau udara;

j. menyelundupkan kayu yang berasal dari atau masuk ke wilayah Negara Kesatuan Republik Indonesia melalui sungai, darat, laut, atau udara;

k. menerima, membeli, menjual, menerima tukar, menerima titipan, dan/atau memiliki hasil hutan yang diketahui berasal dari pembalakan liar;

I. membeli, memasarkan, dan/atau mengolah hasil hutan kayu yang berasal dari kawasan hutan yang diambil atau dipungut secara tidak sah; dan/atau

m. menerima, menjual, menerima tukar, menerima titipan, menyimpan, dan/atau memiliki hasil hutan kayu yang berasal dari kawasan hutan yang diambil atau dipungut secara tidak sah. 


\section{Pengertian Lingkungan Hidup}

Lingkungan adalah kombinasi antara kondisi fisik yang mencakup keadaan sumber daya alam seperti tanah, air, energi surya, mineral, serta flora dan fauna yang tumbuh di atas tanah maupun di dalam lautan, dengan kelembagaan yang meliputi ciptaan manusia seperti keputusan bagaimana menggunakan lingkungan fisik tersebut. Lingkungan di Indonesia sering juga disebut "lingkungan hidup". Misalnya dalam Undang-Undang No. 32 Tahun 2009 tentang Pengelolaan Lingkungan Hidup.

Definisi Lingkungan Hidup adalah kesatuan ruang dengan semua benda, daya, keadaan, dan makhluk hidup, termasuk manusia, dan perilakunya, yang memengaruhi kelangsungan perikehidupan dan kesejahteraan manusia serta makhluk hidup lain dan dapat mempengaruhi hidupnya. ${ }^{3}$ Pengertian lingkungan hidup bisa dikatakan sebagai segala sesuatu yang ada di sekitar manusia atau makhluk hidup yang memiliki hubungan timbal balik dan kompleks serta saling mempengaruhi antara satu komponen dengan komponen lainnya.

Undang Undang UU No 32 Tahun 2009, lingkungan hidup adalah kesatuan ruang dengan semua benda, daya, keadaan, dan makhluk hidup, termasuk manusia dan perilakunya, yang mempengaruhi kelangsungan perikehidupan dan kesejahteraan manusia serta makhluk hidup lain. Sedangkan ruang lingkup lingkungan hidup Indonesia meliputi ruang, tempat Negara Kesatuan Republik Indonesia yang berwawasan Nusantara dalam melaksanakan kedaulatan, hak berdaulat, dan yurisdiksinya

Undang-Undang No. 32 Tahun 2009 menyatakan bahwa perlindungan dan pengelolaan lingkungan hidup adalah upaya sistematis dan terpadu yang dilakukan untuk melestarikan fungsi lingkungan hidup dan mencegah terjadinya pencemaran dan/atau kerusakan lingkungan hidup yang meliputi perencanaan, pemanfaatan, pengendalian, pemeliharaan, pengawasan, dan penegakan hukum.

Undang-Undang No. 32 Tahun 2009 menyebutkan pengertian pencemaran lingkungan hidup adalah masuk atau dimasukkannya makhluk hidup, zat, energi, dan/atau komponen lain ke dalam lingkungan hidup oleh kegiatan manusia sehingga melampaui Baku Mutu Lingkungan hidup yang telah ditetapkan, sedangkan pengertian perusakan lingkungan hidup adalah tindakan orang yang menimbulkan perubahan langsung atau tidak langsung terhadap sifat fisik, kimia, dan/atau hayati lingkungan hidup sehingga melampaui kriteria baku kerusakan lingkungan hidup. ${ }^{4}$

\section{Manfaat dan Fungsi Lingkungan Hidup}

Lingkungan hidup merupakan semua hal yang berada disekitar kehidupan manusia yang keberadaanya secara langsung maupun tidak langsung sangat berpengaruh terhadap kelangsungan hidup manusia serta mahluk hidup lainya. Atau bisa juga didefinisikan sebagai sumber daya yang keberadaanya ikut serta dalam menjamin kelangsungan hidup makhluk hidup di sekitarnya, baik itu manusia maupun makhluk hidup lainya. Ruang lingkup lingkungan hidup di indonesia meliputi ruang, tempat Negara Kesatuan Republik Indonesia yang berwawasan nusantara dalam melaksanakan kedaulatan, hak berdaulat, dan yurisdiksinya.

Terdapat tiga unsur lingkungan, yaitu :

a. unsur hayati (biotik), unsur-unsur lingkungan hidup yang terdiri dari segala jenis makhluk hidup, mulai dari manusia, hewan, tumbuhan, maupun organisme atau jasad renik lainya.

\footnotetext{
${ }^{3}$ N.H.T Siahaan Hukum lingkungan dan ekologi pembangunan, Erlangga, Jakarta , 2004 hlm 4

${ }^{4}$ Harun M husein, Lingkungan Hidup, Bumi Aksara, jakarta , 2000. hlm.19
} 
b. Unsur fisik (abiotik), segala unsur lingkungan yang terdiri dari benda-benda mati seperti air, udara, dan lain sebagainya.

C. Unsur sosial budaya, unsur lingkungan yang diciptakan manusia yang didalamnya terdapat nilai, gagasan, norma, keyakinan serta prilaku manusia sebagai makhluk sosial atau makhuk yang tidak dapat hidup sendiri.

Ketiga unsur tersebut ditas keberadanya saling memiliki keterkaitan atau hubungan satu dengan yang lainya. Misalnya saja keberadaan unsur fisik seperti air dan udaramerupakan faktor penting untuk kelangsungan hidup makhluk hidup. Keberadaan lingkungan hidup telah banyak memberikan manfaat serta fungsi lingkungan bagi manusia dan makhluk hidup lainnya, beberapa fungsi lingkungan hidupan yaitu :

a. Sebagai tempat untuk bertahan hidup

Lingkungan hidup merupakan suatu tempat dimana didalamnya terdapat unsur-unsur yang saling memiliki keterkaitan satu dengan yang lainya, seperti;

1. Ketersediaan udara yang sangat diperlukan untuk sistem pernafasan baik bagi manusi maupun makhluk hidup lainya.

2. Ketersediaan sinar matahari yang bermanfaat sebagai sumber energi cahaya.

3. Ketersediaan air yang dipergunakan untuk minum, mandi, irigasi, pembangkit listrik dn lain sebagainya.

4. Ketersediaan lahan yang merupakan suatu kebutuhan bagi manusia untuk mendirikan sarana dan prasarana yang dapat membantu menunjang kehidupan manusia seperti sarana tempat tinggal, srana tempat pendidikan.

b. Sebagai tempat untuk bersosialisasi

Manusia merupakan makhluk sosial, mereka tidak dapat hidup sendiri tanpa adanya bantuan dari orang lain. Lingkungan hidup menjadi tempat yang strategis bagi manusia untuk menciptakan tempat tinggal yang baik, dimana dalam suatu lingkungan tersebut terdiri dari kumpulan manusia yang hidup saling berdampingan, bekerja sama, dan saling tolong menolong.

c. Sebagai tempat untuk mencari kekayaan

Banyak sekali kekayaan yang terkandung didalam lingkungan hidup, seperti keberadaan barang tambang, hewan, tumbuhan yang dapat mendorong perekonomian manusia jika sumberdayanya dimanfaatkan.

d. Tempat untuk mendpatkan hiburan

Dalam kehidupan manusia tidak hanya membutuhkan makan, minum, pakaian ataupun tempat tinggal, akan tetapi mereka juga memerlukan sarana hiburan agar terhindar dari ras stres ataupun kejenuhan. Di dalam lingkungan banyak sekali menyediakan sarana atupun prasarana untuk memenuhi kebutuhan tersebut.

e. Sebagai sarana edukasi

Lingkungan hidup juga menyediakan sarana pembelajaran bagi manusia, dimana kita bisa melakukan hal-hal untuk menmbah wawasan kita seperti dengan mengaakan penelititan lingkungan.

f. Sebagai sumber kebudayaan

Lingkungan hidup juga memiliki peran yang penting dalam perkembangan seni dan budaya, dimana lingkungan sangat berpengruh terhadap tingkah laku manusia yang menjadi slah satu unsur pembentuk budaya. 


\section{Akibat Yang Timbul Dari Kerusakan Lingkungan Hidup}

Kerusakan lingkungan menjadi masalah yang telah menjadi perhatian dunia secara global. Hal tersebut dikarenakan oleh berbagai kerusakan lingkungan yang terjadi di berbagai negara yang semakin parah, baik di negara maju maupun di negara berkembang. Banyak faktor yang menyebabkan terjadinya kerusakan lingkungan hidup, di antaranya disebabkan oleh berbagai kegiatan industri modern yang menimbulkan dampak negatif terhadap lingkungan serta disebabkan dampak negatif dari kemiskinan. Berbagai masalah kerusakan lingkungan yang banyak terjadi antara lain, kerusakan hutan, erosi tanah, kepunahan satwa liar, kepunahan tumbuh-tumbuhan, dan lain-lain. Adapun bentuk kerusakan lingkungan adalah sebagai berikut;

1. Kerusakan Lingkungan Hidup oleh Faktor Alam

Bentuk kerusakan lingkungan yang disebabkan faktor alam pada umumnya merupakan bencana alam, seperti letusan gunung api, banjir, abrasi, angin puting beliung, gempa bumi, tsunami, dan sebagainya. Adapun kerusakan lingkungan hidup di tepi pantai disebabkan oleh adanya abrasi, yaitu pengikisan pantai oleh air laut yang terjadi secara alami. Peristiwa gempa bumi merupakan kekuatan alam yang berasal dari dalam bumi dan dapat menyebabkan getaran di permukaan bumi. Gempa bumi sering terjadi di berbagai belahan dunia, termasuk di Indonesia sehingga menimbulkan kerusakan pada lingkungan.Kerusakan lingkungan hidup oleh alam terjadi karena adanya gejala atau peristiwa alam yang terjadi secara hebat sehingga memengaruhi keseimbangan lingkungan hidup. Peristiwa-peristiwaalam yang dapat memengaruhi kerusakan lingkungan, antara lain meliputi hal-hal berikut ini.

a. Letusan Gunung Merapi

Letusan gunung api dapat menyemburkan lava, lahar, material-material padat berbagai bentuk dan ukuran, uap panas, serta debudebu vulkanis. Selain itu, letusan gunung api selalu disertai denganadanya gempa bumi lokal yang disebut dengan gempa vulkanik. Aliran lava dan uap panas dapat mematikan semua bentuk kehidupan yang dilaluinya, sedangkan aliran lahar dingin dapat menghanyutkan lapisan permukaan tanah dan menimbulkan longsor lahan. Uap belerang yang keluar dari pori-pori tanah dapat mencemari tanah dan air karena dapat meningkatkan kadar asam air dan tanah. Debu-debu vulkanis sangat berbahaya bila terhirup oleh makhluk hidup (khususnya manusia dan hewan), hal ini dikarenakan debu-debu vulkanis mengandung kadar silika (Si) yang sangat tinggi, sedangkan debu-debu vulkanis yang menempel di dedaunan tidak dapat hilang dengan sendirinya. Hal ini menyebabkan tumbuhan tidak bisa melakukan fotosintesis sehingga lambat laun akan mati. Dampak letusan gunung memerlukan waktu bertahun-tahun untuk dapat kembali normal. Lama tidaknya waktu untuk kembali ke kondisi normal tergantung pada kekuatan ledakan dan tingkat kerusakan yang ditimbulkan. Akan tetapi, setelah kembali ke kondisi normal, maka daerah tersebut akan menjadi daerah yang subur karena mengalami proses peremajaan tanah.

b. Gempa Bumi

Gempa bumi adalah getaran yang ditimbulkan karena adanya gerakan endogen. Semakin besar kekuatan gempa, maka akan menimbulkan kerusakan lingkungan hidup yang semakin parah di muka bumi. Gempa bumi menyebabkan bangunanbangunan retak atau hancur, struktur batuan rusak, aliran-aliran sungai bawah tanah terputus, jaringan pipa dan saluran bawah tanah rusak, dan sebagainya. Jika kekuatan gempa bumi melanda lautan, maka akan menimbulkan tsunami, yaitu arus gelombang pasang air laut yang menghempas daratan dengan kecepatan yang sangat tinggi. 
C. Banjir

Banjir merupakan salah satu bentuk fenomena alam yang unik. Dikatakan unik karena banjir dapat terjadi karena murni gejala alam dan dapat juga karena dampak dari ulah manusia sendiri.Banjir dikatakan sebagai gejala alam murni jika kondisi alam memang memengaruhi terjadinyabanjir, misalnya hujan yang turun terus menerus, terjadi di daerah basin, dataran rendah, atau dilembahlembah sungai. Selain itu, banjir dapat juga disebabkan karena ulah manusia, misalnya karena penggundulan hutan di kawasan resapan, timbunan sampah yang menyumbat aliran air, ataupun karena rusaknya dam atau pintu pengendali aliran air. Kerugian lingkungan yang ditimbulkan akibat banjir, antara lain, hilangnya lapisan permukaan tanah yang subur karena tererosi aliran air, rusaknya tanaman, dan rusaknya berbagai bangunan hasil budidaya manusia. Bencana banjir merupakan salah satu bencana alam yang hampir setiap musim penghujan melanda di beberapa wilayah di Indonesia.

d. Tanah Longsor

Karakteristik tanah longsor hampir sama dengan karakteristik banjir. Bencana alam ini dapat terjadi karena proses alam ataupun karena dampak kecerobohan manusia. Bencana alam ini dapatmerusak struktur tanah, merusak lingkungan lahan pertanian, pemukiman, sarana dan prasarana penduduk serta berbagai bangunan lainnya. Peristiwa tanah longsor pada umumnya melanda beberapa wilayah Indonesia yang memiliki topografi agak miring atau berlereng curam.

2. Kerusakan Lingkungan Hidup yang Disebabkan oleh Kegiatan Manusia

Proporsi kerusakan lingkungan yang disebabkan kegiatan manusia sebetulnya jauh lebih besar dibandingkan dengan kerusakan lingkungan yang disebabkan oleh alam. Bentuk keruskan lingkungan yang disebabkan oleh manusia di antaranya pencemaran sungai oleh limbah industri, penebangan hutan secara massal dan ilegal, dan sebagainya. Penebangan-penebangan hutan untuk keperluan industri, lahan pertanian, dan kebutuhan-kebutuhan lainnya telah menimbulkan kerusakan lingkungan hidup yang luar biasa. Kerusakan lingkungan hidup yang terjadi menyebabkan timbulnya lahan kritis,ancaman terhadap kehidupan flora dan fauna, dan kekeringan.

Pencemaran lingkungan dapat terjadi terhadap air, tanah, dan udara. Pada umumnya, pencemaran air dan tanah terjadi karena pembuangan limbah-limbah industri dan biasanya terjadi di perkotaan. Adapun pencemaran terhadap udara terjadi karena hasil pembakaran bahan bakar. Kasus-kasus pencemaran perairan telah sering terjadi karena pembuangan limbah industri ke dalam tanah, sungai, danau, dan laut. Kebocoran-kebocoran pada kapal-kapal tanker dan pipa-pipa minyak yang menyebabkan tumpahan minyak ke dalam perairan menyebabkan kehidupan di tempat itu terganggu, banyak ikan-ikan yang mati, tumbuh-tumbuhan yang terkena genangan minyak pun akan musnah pula. Masyarakat yang mempunyai mata pencarian menangkap ikan seperti nelayan terimbas pula dampak negatifnya, yaitu berkurangnya jumlah tangkapan ikan yang mereka peroleh. Masalah lain yang muncul adalah perladangan hutan secara liar oleh penduduk. Akibatnya keanekaan flora dan fauna hutan menurun drastik, serta manfaat hutan bagi manusia pun terganggu bahkan hilang sama sekali. 


\section{PEMBAHASAN}

\section{Penerapan Sanksi Pidana terhadap pelaku tindak pidana perusakan hutan lindung menurut Undang-Undang Nomor 32 Tahun 2009 Tentang Perlindungan dan Pengelolaan Lingkungan Hidup}

Tindak pidana perusakan hutan lindung terkait dengan perbuatan yang mengakibatkan terjadinya pencemaran dan atau perusakan lingkungan hidupsehingga harus mendapat perhatian khusus dari semua pihak. Perusakan lingkungan hidup merupakan tindakan yang menimbulkan perubahan langsung atau tidak langsung terhadap sifat fisik dan atau hayatinya yang mengakibatkan lingkungan hidup tidak berfungsi lagi dalam menunjang pembangunan berkelanjutan. UUPPLH memuat beberapa ketentuan larangan pengelolaan dan pemanfaatan lingkungan hidup dengan tidak memperhatikan kelestarian lingkungan. Undang-undang ini menyatakan bahwa salah satu parameter dalam baku kerusakan lingkungan adalah kriteria baku kerusakn lingkungan yang diakibatkan karena kegiatan manusia.

Dalam kasus yang terjadi di Kabupaten Garut dan Kabupaten Bandung memang bukan hanya terjadi oleh masyarakat yang membuka lahan tetapi juga terjadi karena pendirian tempat usaha ataupun tempat wisata yang dilakukan oleh perusahaa dan tidak memperhatikan kelestarian lingkungan, bahkan banyak yang tidak memiliki izin usaha.Terkait kasus yang terjadi Dikabupaten Garut sampai saat ini telah ditetapkan 7 tersangka terkait masalah alih fungsi kawasan hutan lindung di kawasan Darajat Pasirwangi, ketujuh tersangka tersebut telah melanggar masalah perizinan dan Undang-Undang mengenai Perlindungan dan Pengelolaan Lingkungan Hidup. Menurut Kabid Humas Polda Jawa Barat Kombes Yusri Yunus menyatakan seluruh tersangka telah melanggar UU No 32 Tahun 2009 tentang Perlindungan Dan Pengelolaan Lingkungan Hidup Pasal 98 ayat (1) dan Pasal 109. Penerapan pasal yang diterapkan kepada tersangka dirasa sudah tepat, karena seluruh tersangka tidak memiliki izin untuk melakukan aktivitas dikawasan hutan lindung sehingga menimbulkan kerusakan hutan dan bencana alami disekitar kawasan hutan tersebut. Tetapi meski demikian dewasa ini tindak pidana perusakan terhadap hutan lindung masih banyak terjadi baik dari segi perizinan ataupun alih fungsi lahan yang dapat menimbulkan berbagai kerugian.

Untuk kasus yang terjadi dikabupaten bandung polisi telah memeriksa 6 orang saksi yang keseluruhan mereka adalah penggarap lahan yang dibuka secara ilegal dengan cara menebang pohon secara liar. Dalam kasus pembukaan lahan di Kabupaten Bandung ini para pembuka lahan hutan lindung yang dijadikan lahan pertanian hanya diberikan peringatan, arahan dan diberikan larangan untuk tidak menempati atau menggarap kawasan hutan lindung tersebut. Sebenarnya UUP3H telah mengtur mengenai penebangan pohon dikawasan hutan lindung secara ilegal seperti tertuang dalam pasal 82 ayat (2). Tetapi meski demikian karena UUPPLH maupun UUP3H menganut asas subsidiaritas maka ketentuan pidana menjadi upaya terakhir dalam penyelesaian kasus tersebut. Namun seharusnya meski demikian hal tersebut tidak menjadi penghalang penuntutan pidana terhadap pelaku perusakan hutan tersebut, karena penerapan asas subsidiaritas menjadi sangat fleksibel jika melihat penjelasan umum angka 7 UUPPLH.

Ketentuan pidana dalam UUP3H merupakan upaya preventif sekaligus represif dalam menegakan hukum di bidang kehutanan. Hal itu dilakukan untuk melindungi dan mengelola lingkungan hutan Indonesia berdasarkan asas tanggung jawab negara, asas keberlanjutan, asas keadilan, juga pengelolaan hutan harus memberikan kemanfaatan ekonomi, sosial, budaya yang dilakukan secara kehati-hatian, demokrasi lingkungan, desentralisasi serta pengakuan terhadap kearifan lokal dalam mengelola lingkungan hidup. Namun upaya represifpenegakan hukum dibidang kehutanan harus dipandang ebgai upaya terakhir (ultimum remedium), yaitu upaya terakhir guna mempengaruhi tingkah laku manusia serta memberikan teknan psikologis agar orang lain tidak melakukan kejahatan. 


\section{Upaya Pencegahanterhadap Tindak Pidana Perusakan Hutan Lindung}

Beberapa upaya yang dapat dilakukan untuk pencegahan terhadap tindak pidana perusakan hutan diantaranya :

1. Upaya preventif

Usaha pencegahan untuk mengurangi atau menghilangkan kemungkinan terjadinya suatu kejadian yang tidak di inginkan di masa depan, merupakan usaha pelestarian lingkungan hidup sebelum lingkungan hidup tersebut menjadi rusak. Upaya ini dapat dilakukan dengan beberapa cara diantaranya :

a. Pembatasan kegiatan eksploitasi sumber-sumber daya alam, seperti penebangan pohon secara liar.

b. Penghematan sumber-sumber daya alam.

c. Melakukan tebang tanam.

d. Mengadakan sosialisasi pentingnya hutan lindung.

e. Ikut mengawsi kegiatan yang dilakukan di areal hutan.

2. Upaya Represif

Upaya ini merupakan upaya untuk mengembalikan keserasian yang pernah terganggu karena terjadinya suatu pelanggaran dengan cara menjatuhkan sanksi sesuai dengan pelanggaran yang dilakukan. Dalam upaya ini dpat dilakukan beberapa cara yaitu

a. Menerapkan sanksi pidana ataupun administrasi terhadap pelanggar.

b. Penutupan tempat usaha.

c. Penghentian kegiatan.

d. Pencabutan izin.

\section{Upaya Kuratif}

Upaya kuratif merupakan upaya perbaikan lingkungan hidup yang sudah terlanjur rusak, untuk mengembalikan lingkungan kepada kondisi semula. Dalam upaya pencegahan tindak pidana perusakan hutan terdapat beberapa upaya kuratif diantaranya:

a. Kegiatan penanaman hutan kembali terhadap hutan-hutan yang sudah terlanjur gundul, seperti yang terjadi dikabupaten Bandung yang dilakukan oleh TNI dan masyarakat.

b. Melakukan penanaman jenis pohon tertentu, penanaman unsur-unsur yang diperlukan tanah (unsur hara dan air)

c. Kegiatan rehabilitasi lahan kritis, misalnya pada tanah longsor. Kegiatan rehabilitasi bisa dapat dilakukan dengan penanaman pohon-pohon berakar kuat.

\section{PENUTUP}

\section{Kesimpulan}

Sanksi pidana yang diterapkan terhadap perusahaan-perusahaan yang telah melanggar perizinan dalam kasus perusakan hutan lindung di Kabupaten Garut adalah Pasal 98 ayat (1) dan Pasal 109 UUPPLH karena di anggap telah memenuhi unsur-unsur didalam pasal tersebut. Karena akibat yang telah ditimbulkan dari tindak pidana tersebut sudah sepatutnya para pelaku dihukum dengan seadil-adilnya. Untuk kasus yang terjadi dikabupaten Bandung para pelaku hanya mendapat binaan serta arahan dari pihak terkait untuk tidak menggunakan areal hutan dengan tidak bijaksana, hal ini dilakukan karena semua pelaku adalah warga setempat yang bersinggungan langsung dengan kawasan terebut. Tetapi meski demikian seharusnya hal tersebut tidak menghilangkan tindak pidana yang telah diperbuat dan seharusnya pelaku tetap diterapkan pasal mengenai tindak pidana yang terdapat dalam UPPLH atau UUP3H.

Upaya pencegahan terhadap tindak pidna perusakan hutan itu telah diatur didalam UUP3H dimana bukan hanya pemerintah atau instansi terkait yang berperan terhadap 
pencegahan tindak pidana perusakan hutan tersebut, melainkan ada peran-peran masyarakat yang sangat penting dalam menjaga kawasan hutan agar tetap utuh dan terjaga kelestarianya diantaranya menjadikan masyarakat mitra lembaga pemberantasan perusakan hutan, dan juga melibatkan masyarakat dalam pengawasan kegiatan di kawasan hutan. Adapun upaya yang dapat dilakukan dengan upaya preventif yaitu upaya Pembatasan kegiatan eksploitasi sumbersumber daya alam, seperti penebangan pohon secara liar, Penghematan sumber-sumber daya alam, Melakukan tebang tanam, Mengadakan sosialisasi pentingnya hutan lindung, Ikut mengawsi kegiatan yang dilakukan di areal hutan. Upaya Represif yaitu Menerapkan sanksi pidana ataupun administrasi terhadap pelanggar, Penutupan tempat usaha, Penghentian kegiatan, dan/atau Pencabutan izin. Dan upaya kuratif,Kegiatan penanaman hutan kembali terhadap hutan-hutan yang sudah terlanjur gundul, seperti yang terjadi dikabupaten Bandung yang dilakukan oleh TNI dan masyarakat, Melakukan penanaman jenis pohon tertentu, penanaman unsur-unsur yang diperlukan tanah (unsur hara dan air), Kegiatan rehabilitasi lahan kritis, misalnya pada tanah longsor Kegiatan rehabilitasi bisa dapat dilakukan dengan penanaman pohon-pohon berakar kuat.

\section{Saran}

Penegakan hukum yang dilakukan oleh penegak hukum harus lebih tegas dan cepat, menginget fungsi hutan lindung sebagai perlindungan sistem penyangga kehidupan untuk mengatur tata air, mencegah banjir, mengendalikan erosi, mencegah intrusi air laut, dan memelihara kesuburan tanah. Perlu adanya kerjasama yang baik antara pihak kepolisian, perhutani dan juga polisi hutan untuk mengawasi aktifvitas yang terjadi dikawasan hutan lindung. Harus adanya penindakan tegas terhadap setiap pelaku terkait perusakan hutan lindung.

Pengawasan serta peran aktif pemerintah daerah harus ditingkatkan dalam rangka mencegah semakin meluasnya perusakan hutan lindung. Diperlukan adanya penyuluhan untuk masyarakat terutama di wilayah sekitar hutan mengenai undang-undang yang mengatur tentang lingkungan hidup terutama hutan serta mengenai dampak-dampak yang dapat ditimbulkan dari kerusakan lingkungan hidup terutama hutan. Menjalin kerjasama dengan masyarakat dan diadakanya pembinaan terhadap masyarakat untuk bagaimana tata cara kelola hutan yang baik.

\section{DAFTAR PUSTAKA}

Ahmad Redi, Hukum Sumber Daya Alam Dalam Sektor Kehutanan, Sinar Grapika, Jakarta, 2014.

Bambang Eko Supriadi, Hukum Agraria Kehutanan: Aspek Hukum Pertanahan Dalam Pengelolaan Hutan Negara, PT.Raja Grapindo Persada, Depok, 2013.

Gatot Suparmono, Penyelesaian Sengketa Lingkungan Hidup di Indonesia, Rineka Cipta, Jakarta, 2013.

Harun M Husein, Lingkungan Hidup, Bumi Aksara, Jakarta, 2000.

Imam Syaukani dan A Ahsin Tohari, Dasar-Dasar Politik Hukum, Raja Grapindo Persada, Jakarta, 2004.

Moeljatno, Asas-Asas Hukum Pidana, Bina Aksara, Jakarta, 1987.

Muhamad Yamin, Tindak Pidana Khusus, Pustaka Setia, Bandung, 2012.

N.H.T Siahan, Hukum Lingkungan Dan Ekologi Pembangunan, Erlangga, Jakarta,2004.

R.Abdoel Djamali, Pengantar Hukum Indonesia, PT.Raja Grapindo Persada, Jakart, 2013.

Supardi, Hukum Kehutanan Dan Perkebunan Di Indonesia, Sinar Grapika, Jakarta, 2011.

Undang-Undang Dasar Negara Republik Indonesia Tahun 1945. 
Undang-Undang Republik Indonesia Nomor 32 Tahun 2009 Tentang Perlindungan Dan Pengelolaan Lingkungan Hidup.

Undang-Undang Republik Indonesia Nomor 18 Tahun 2013 Tentang Pencegahan Dan Pemberantasan Perusakan Hutan.

Undang-Undang Republik Indonesia Nomor 41 Tahun 1999 Tentang Kehutanan. 